oxidising the nitrogen of organic matter and of ammonia, and thus producing nitric acid.

The organisms which produce these wonderful changes consist of colourless cells; they are independent of daylight, for they derive their supply of carbon exclusively from organised matter, and from the decomposition of such matter they obtain the force necessary for life and growth. In these respects they differ entirely from green veretation, in which sunlight is the source of all energy, and carbonic acid gas, decomposed by the aid of light, the material from which carbon is derived. The colourless and green organisms, however, equally require phosphoric acid, potash, and other ash constituents; and both appear to be capable of assimilating nitrogen in the form of ammonia.

Not only are these simple organisms independent of the aid of light, but light is, in some cases at least, actually fatal to their existence. This fact has quite recently been established by Downes and Blunt. They find that the bacteria present in an organic fluid may in many cases be entirely destroyed by exposure of the solution to daylight, and that even when this is not the case, their development is much retarded by such treatment. This observation is perfectly in accordance with the fact observed at Rothamsted, that nitrification did not proceed in solutions exposed to daylight. "In the last communication of Schloesing and Müntz, it is stated that vegetable soil suspended in water by passing a stream of air through the mixture, undergoes nitrification both in light and darkness. No details of the experiment are given, but it seems probable that such a mixture would be more or less opaque, and the greater bulk of the material consequently at all times in partial darkness.

The microscopic organism producing nitrification has probably distinctive characters, and might be isolated by cultivation under conditions specially suitable to its growth, but more or less unfavcurable to the life of other associated germs. Pasteur has pursued this method with success in the case of beer yeast, and has shown that with the pure yeast thus obtained an unchangeable beer may be manufactured, the organisms producing secondary changes having been excluded. The subject of nitrification has clearly reached a stage which demands the aid of the vegetable physiologist.

R. WARINGTON

\section{FOSSIL HUNTING AT BOURNEMOUTH}

I HAVE recently deposited in the South Kensington Museum some unusually large specimens of fossil plant remains from Bournemouth and Studland. The matrix in which these are imbedded is friable, and the remains, in most cases, are extremely difficult to extract, so that a brief account of the process employed may be of use to would-be collectors. The largest specimen, part of the frond of a feather-palm, measures $4 \mathrm{ft}$. by $3 \mathrm{ft}$., and as this presented the greatest difficulties, I will more particularly describe the work which its preservation involved.

In digging last autumn at Bournemouth in a bed of dark clay about 60 feet above the sea-level, and about the same distance from the top of the cliff, we came across a well-preserved fragment of this specimen consisting of a portion of the stem with the bases of pinnæa attached. We included a younger athletic brother, a coast-guardsman whom I have long employed, as well as myself, and occasional other assistance. The tools we used were pick-axes, crow-bar, and spades. The place was a slightly projecting ledge, none too solid, with a steep cliff above and below. So soon as the fragment mentioned was brought to light by a stroke of the pick digging was stopped, and a careful examination was made by the aid of our knives to see in which direction the frond trended. Finding, fortunately, that the direction was towards the mass of the cliff, we determined to use our endeavours to extract it in as perfect a condition as might be. We therefore, at about mid-day, commenced to dig away the superincumbent mass until a slab was bared at least twice the size of that ultimately required, when we proceeded to clear down and lay bare the specimen. Loose sand blowing up in clouds, however, settled upon it and threatened to adhere so firmly to the wet clay that it was feared it might be found impossible to remove it, whilst the drying action of the wind caused it to crack and peel, notwithstanding all our efforts to keep it covered with damp paper and linen. It was then determined to remove the slab without exposing the leaf, leaving that operation until it was safely housed at home, and we therefore commenced the laborious operation of undermining this great slab and removing it in such pieces as from time to time broke away by their own weight from the main mass. For five hours these pieces kept breaking away in blocks of about one foot in thickness, and as much in weight as two or three of us could lift. At dusk our task was not more than two-thirds completed, but as wet was expected, it was determined to extract the whole that night if possible. Perhaps the most toilsome part of the work was carrying the pieces up the sixty feet of cliff. A hand-barrow having been improvised, it required our united efforts to convey each piece to the path above, and this was really hard work, and in addition I had great anxiety throughout lest the edges should be rubbed. Notwithstanding all our trouble we had the mortification of seeing our large lumps repeatedly break and subdivide. The work went on until about 9 P.M., when we found it impossible to continue, and therefore carefully covered up the remains of the slab, the vicinity of a populous town rendering this precaution necessary. The next day the whole of the pieces were removed in a cart from the coast-guards station to an out-house in our occupation. When they arrived therc the prospect was far from hopeful. We had apparently but a truckful of lurnps of black wet. clay, a foot or more in thickness, and varying in diameter from a few inches to two or three feet, the majority without trace of the fossil upon them, or any marks or indication of how they were to be fitted together. Experience among these fossils has taught me not easily to clespair, and I knew, moreover, from the care that had been taken, that the edges could not be much abraded, nor could any considerable pieces be missing. Our lodging contained a new and comparatively well-lit cellar, to which all was removed. A table was next made, six feet long and four feet wide, and portions of three days occupied in ascertaining how the pieces could be fitted together.

Two days were then lost in fastening the smaller pieces together into larger slabs, but it was found that these larger pieces would not come together properly in the box, their relative thickness, \&c., being different. They were next reduced in thickness to about three inches and transferred to the box in which they now are, and fitted together as accurately as possible and fixed by glue and plaster of Paris, $\frac{3}{4} \mathrm{cwt}$. of the latter being used.

A great disappointment now awaited us. From standing and kneeling upon the slab whilst engaged in digging it out, the upper surface of the leaf was kneaded into the under surface, and would not part for weeks afterwards, until quite dry, and then in very small fragments only.

Another difficulty was that two other fronds were found at lower levels traversing the one we were endeavouring to save, and in some places these had been cleaned out before the mistake was discovered. The base of the frond, it will be seen, has been abandoned altogether; and not more than two-thirds is now preserved. The next thing was to get it to London safely, and the railway officials were cautioned as to the care required and the necessity of keeping it flat and right side up, and the case was 
insured. Even while I was in the office insuring it a stupid porter tilted it over face downwards to my great grief, as I had little hope that the plaster would hold with such a weight if the case were subjected to this treatment on the way. I was relieved in my mind a few days later by its safe arrival at home. From this time patience alone was required, and by Christmas, with the aid of Mr. De Wilde, the whole leaf was uncovered and varnished and all the cracks filled in with modelling clay.

The other specimens were obtained in more or less the same way. The small feather palm was extracted whole with the assistance of Mr. Henry Keeping, of the Woodwardian Museum, but fell to pieces on the shutter to which it was transferred for carriage, and great care was needed to put them together as they now are. The Studland fan-palm being rotted by exposure on the face of the cliff and being penetrated everywhere by rootlets, fell into a hundred pieces, and only the centre of the leaf could be pieced together the rest being pulverised in its journey from Studland to Wareham.

\section{J. S. GARDNER}

\section{FATHER SECCHI}

COME little time ago we announced the serious illness of Father Secchi, the well-known astronomer and Director of the Observatory of the Collegio Romano, at Rome; last week we chronicled his death, which occurred on the 26th ult. The illness which has thus terminated fatally, has cut him off, we may say, in the prime of his life, and in the midst of his work; for, till he was taken ill, there were no signs of any diminution of his encrgy, and he was only fifty-nine years of age when he died.

Secchi was born at Reggio, on June 29, I8I8. Educated and trained from early youth as a Jesuit, we hear of him first in connection with science as Professor of Physics at Georgetown College, near Washington, and next as holding the same chair in the Roman College at Rome. It was in connection with the observatory attached to this institution that almost all Secchi's work for the last thirty years has been done. While the Roman College was in papal hards no funds were spared to make the observatory as complete as possible. Secchi had instruments and assistants in abundance, and his various serics of "Memoirs" testify to his industry in many fields, while his position gave him great facilities for giving the widest publicity to his work. What he lacked in originality he made up in assiduity, and hence, although he has left no great life work on any one subject behind him there is, we think, hardly any question which has turned up touching observations in astronomy, magnetism or meteorology on which a multitude of papers have not been written by his busy pen. Many of these papers are very admirable and show great penetration and power of generalisation as well as a wide grasp of many subjects.

Secchi's great interest in solar physics was doubtless aroused, when in America, by assisting Prof. Henry in making the first experiments on the heat radiated by different portions of the sun's disc by means of the thermo-electric pile. His interest in spectroscopy dates from Janssen's visit to Rome, when on his scientific mission to Italy and Greece. In both these branches of work Secchi has been an ardent observer and voluminous writer. He photographed the eclipse of 1860 in Spain, and observed the one of 1870 in Sicily. In 1867 he was in Paris exhibiting his universal meteorograph in the exhibition of that year, and giving lectures, some of which eventually formed the basis of his book on the Sun, a second edition of which appeared last year. Besides this book on the Sun, he has written others on the Unity of the Physical Forces, and on the Stars, the latter of which has not yet appeared.

When the States of the Church became Italian the Roman College was among the institutions which were turned to other uses by the new government. This now contains two most interesting museums, one of educational apparatus chiefly for primary instruction, and another for antiquities. The new Government, however, were extremely anxious not to interfere with Sccchi's scientific labours and offered him the Chair of Astronomy in the new Roman University, at the same time granting ample funds for the prosecution of his inquiries. This Secchi accepted, but soon found his occupation gone, as he was commanded by the chief of the Jesuits to resign it, which he did. It is doubtful whether any modus viventil would have been found if the king, whose foster. brother he was, had not stepped in between the Ministry and the Yatican, and suggested a compromise which would have left Secchi to continue his work under most favourable conditions, if the Jesuits had not again stepped in.

One of the most recent results of Secchi's energy has been the foundation of the Societá degli Spettroscopisti Italiani, a society specially constituted for recording daily spectroscopic observations of the sun, chiefly at the various observatories of Italy.

There is no doubt that in the death of Father Secchi observational astronomy has sustained a great loss. His industry and skill were largely rewarded during his lifetime. In 1867 he received the great French prize of 100,000 francs. He was a member of most scientific socicties, including our own Royal Society, and it must not be forgotten that if there may have been traits of Secchi's character open to criticism, the exigencies of his post, rather than the inclinations of the man, may have bcen to blame.

\section{NOTES}

THE French expedition for the observation of the approaching transit of Mercury consists of M. C. André and M. Angot, who formed likewise part of the expedition to New Caledonia, on the occasion of the transit of Venus. Ogden, in the State of Utah, has been selected by the French Institute as the most favourable locality for the observation, and the expedition is already under way to its ciestination. A Parisian nillionaire, well known for his generosity towards scientific objects, has contributed 30,000 francs to defray the expenses of the observation.

WE regret to learn of the dangerous illness of the well-known mineralogist, M. Delafosse Gabriel, professor at the Muséum d'HIistoire Naturelle of Paris. H He is now in his eighty.third year, and has been for twenty years a member of the French Academy of Sciences.

THE Royal Academy of Sciences at Berlin has elected the well-known Prof. Noeldecke, of Strassburg, a corresponding member.

ARRANGEMENTS are being made at l'aris for the erection of a fitting monument to the late Claude Bernard. The initiative has been made by the Société de Biologie, of which Bernard was one of the founders, and over the meetings of which he has presided during the past eleven years. The committee appointed for the purpose contains prominent names from all the leading scientific institutions of Paris.

THE death is announced of Mr. Joseph Bonomi, the distinguished Egyptologist, which occurred at Wimbledon Park on Sunday last, at the age of eighty-two. For the last sixteen years Mr. Bonomi has acted as Curator of the Soane Museum in Lincoln's Inn Fields. Mr. Bonomi went out to Egypt as early as 1824, and spent eight years on the banks of the Nile, drawing and studying the ancient temples and their wonderful sculptures. During this time he had adopted the Arab costume and mode of living, and by this means he was able to go on in the prosecution of his studies with his then limited resourceș. He rețurnest 